\title{
DEVELOPMENT OF URBAN COMMUNITY THROUGH CREATIVE BUSINESS GROUPS TOWARDS INDEPENDENT VILLAGE IN MENTENG VILLAGE JEKAN RAYA DISTRICT PALANGKA RAYA CITY
}

\author{
Noor Hasanah ${ }^{1}$, Ries Dyah Fitriyah ${ }^{2}$ \\ 1,2Sunan Ampel State Islamic University, Surabaya, Indonesia \\ ${ }^{1}$ ninoor.hasanah@gmail.com, ${ }^{2}$ risdyah@gmail.com
}

\begin{abstract}
The purpose of this research is to find a strategy in developing Creative Business Groups in Menteng Village, precisely in the RT 05/RW XII environment and its surroundings. The group's efforts have been to recycle used tires into useful items, for example making flower pots and others, focusing on the environmental theme. Furthermore, mentoring is carried out because the group understands that they have potential in the field of business for the development of their group. They mobilize the community to join together in managing the business and its environment in collaboration with stakeholders (RT). The strategy used is to analyze pentagonal assets and determine asset advantages using the Orid Technique, which is then described in the program strategy analysis table (related to program potential, expectations, and plans). The summary of the agreed program is to strengthen group management and design development efforts for infrastructure development before the business is realized. The Asset Based Community-Driven Development (ABCD) approach is used as the method of this action research, namely community development carried out based on the assets owned, namely human, social, and supportive environmental assets. Community development process with independent participation (self-mobilization) through Appreciative Inquiry. The discovery of data is covered in the FGD process, interviews, observation and documentation, and the evaluation techniques used are before-after and historical plots. Program changes can be analyzed by looking at the development of a more structured group management and realizing the development of a business development plan. So that if the business starts operating, in the future it can have an impact on strengthening the economy, social and environment of the community.
\end{abstract}

Keywords: Assets, Business Group, Community Development, Environment, Management, Self-Mobilization.

Abstrak: Tujuan dari penelitian ini adalah untuk mengetahui strategi dalam mengembangkan Kelompok Usaha Kreatif di Desa Menteng tepatnya di lingkungan RT 05/RW XII dan sekitarnya. Upaya yang dilakukan kelompok adalah mendaur ulang ban bekas menjadi barang yang bermanfaat, misalnya membuat pot bunga dan lainlain, dengan fokus pada tema lingkungan. Selanjutnya pendampingan dilakukan karena kelompok memahami bahwa mereka memiliki potensi di bidang usaha untuk pengembangan kelompoknya. Mereka menggerakkan masyarakat untuk bersamasama mengelola usaha dan lingkungannya bekerja sama dengan pemangku kepentingan (RT). Strategi yang digunakan adalah menganalisis aset pentagonal dan menentukan keunggulan aset menggunakan Teknik Orid, yang kemudian dijabarkan dalam tabel analisis strategi program (terkait potensi program, harapan, dan rencana). Rangkuman dari program yang disepakati adalah untuk memperkuat manajemen kelompok dan merancang upaya pengembangan untuk pembangunan infrastruktur sebelum bisnis direalisasikan. Pendekatan Asset Based CommunityDriven Development (ABCD) digunakan sebagai metode penelitian tindakan ini, yaitu 
community development yang dilakukan berdasarkan aset yang dimiliki yaitu aset manusia, sosial, dan lingkungan yang mendukung. Proses pengembangan masyarakat dengan partisipasi mandiri (self-mobilization) melalui Appreciative Inquiry. Penemuan data meliputi proses FGD, wawancara, observasi dan dokumentasi, serta teknik evaluasi yang digunakan adalah before-after dan history plot. Perubahan program dapat dianalisa dengan melihat perkembangan pengelolaan kelompok yang lebih terstruktur dan merealisasikan pengembangan rencana pengembangan usaha. Sehingga jika usaha tersebut mulai beroperasi, kedepannya dapat berdampak pada penguatan ekonomi, sosial dan lingkungan masyarakat.

Kata kunci: Aset, Kelompok Usaha, Bina Lingkungan, Lingkungan, Pengelolaan, Mobilisasi Diri.

\section{A. Introduction}

Creativity is one of the characteristics of Menteng Village in RT 05/RW XII, there are 10 community members who focus on developing their area by recycling or recycling goods to become more useful by processing used tires into useful goods. Recycled products that are created are Plant Pots that seem strong, durable, and creative or of artistic value. In addition, there are other products or decorations that are processed with the basic ingredients of used tires, which can be seen in the Accessories or decorations of the Balanga Menteng Park in RT 05/RW XII. The park is a creative effort carried out in 2020, this group won the favorite champion in the healthy, clean, and creative village competition.

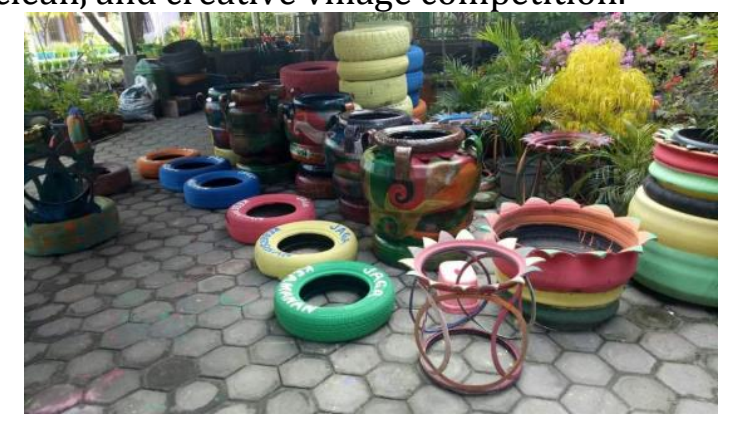

Figure 1 Examples of Business Group Products

Other products that have been successfully created include Balanga (jars), cartoon and animal miniatures, tire railings, chairs, and even swing seats. Successfully carrying out these efforts with their capacity in revitalizing the environment, at the end of 2020 they agreed to transform into a business group, by developing their capacity to become more valuable.

Besides this, it turns out that the form of Taman RT 05/RW XII has succeeded in inspiring government agencies within the Menteng Urban Village to participate in carrying out spatial planning in the environment around the Menteng Village Office. The village provided funds for the construction of the park, until finally Menteng Urban Village Park was successfully completed on February 14, 2021. The system was carried out in collaboration with representatives of the creative business group of 5 people and 5 people from the Menteng village.

Building a Park is said to be a form of development cooperation, a form of Stakeholder support from the Government, and as a manifestation of the success of the Creative Business Group in creating a healthy environment. This is a way of promoting the group's creativity apart from using social media, as a result, this group managed to sell its processed products while working on the Menteng sub-district park.

The business runs for one month getting a turnover of 2 million less capital, so that each person has a profit of 100 thousand / person multiplied by 10 members. After that, in midFebruary the group agreed to develop its group so that the business has more economic value 
than before, by analyzing the potential, expectations, and plans for further programs. The next group development effort is to innovate to create development efforts to make sustainability efforts or maintain the survival of community members, in accordance with the actual development concept.

Of course, in realizing this, community participation is very important in it. Participation is an element of development in community development and empowerment programs. ${ }^{1}$ Moreover, this sustainability is carried out based on the agreement and willingness of group members, which reflects independent community participation. Strengthening potential in carrying out group management is expected to be able to walk side by side with elements in the community, and be able to mobilize potential and reduce challenges in their environment, economy, and social, so that they can go to the independent village they aspire to.

\section{B. Theoretical Review}

\section{Community Development: Group Self Mobilization}

Community development is a process of community restructuring (rearrangement) with participatory self-help in managing socio-economic life so that it can meet its own needs compared to previous times. Community development aims to develop the ability of lower-level communities to identify needs, access resources to meet their needs and empower them together and ultimately have strong control over their own lives. ${ }^{2}$

Community development is the initial stage towards the community empowerment process, ${ }^{3}$ with efforts to develop a sustainable and active community condition. ${ }^{4}$ Focused on efforts to help weak people who have an interest in working together in groups, identify needs and jointly implement development programs that provide the power to fulfill needs or fulfill the needs of responsible parties with social action. ${ }^{5}$ Community development can be defined as a method that improves the quality of life and is able to increase its influence on the processes that affect their lives.

All community development activities are directed at forming a community structure that reflects the growing spirit of self-reliance and participation. Community development includes efforts to strengthen social interaction in the community, create a spirit of togetherness, solidity among community members and help them to communicate with other parties by means of dialogue naturally or without intervention, based on full understanding and followed up with real social action. ${ }^{6}$

Community development is a verb, which means that society is not the goal or result of a community process called an object, but is a process of change. ${ }^{7}$ Take control over existing resources to be used or exploited i.e. People mobilize themselves. Self-mobilization is the highest level of participation that shows the empowerment of the community, where the community controls all development processes. So that the slogan of development from, by, and for the people can be implemented in real terms and maximally at this level of participation.

Here the community is able to develop contacts with other institutions for assistance or technical support, as well as the necessary resources. There are two characteristics of independent participation, namely:

\footnotetext{
1 Shomedran, "Pemberdayaan Partisipastif dalam Membangun Kemandirian Ekonomi dan Perilaku Warga Masyarakat (Studi Pada Bank Sampah Wargi Manglayang RT 01 RW 06 Kelurahan Palasari Kecamatan Cibiru Bandung)", Jurnal Pendidikan Luar Sekolah, (online), vol. 12, no. 2, 2016, 8.

2 Zubaedi, Pengembangan Masyarakat: Waacana dan Praktek, (Jakarta: Kencana, 2013), 2.

${ }^{3}$ Zubaedi, Pengembangan Masyarakat, 2.

4 Zubaedi, Pengembangan Masyarakat, 5.

5 Zubaedi, Pengembangan Masyarakat, 6.

6 Zubaedi, Pengembangan Masyarakat, 6-7.

7 Jim Ife dan Frank Tesoriero, Community Development: Alternatif Pengembangan Masyarakat di Era Globalisasi, Penj. Sastrawan Manulang, dkk. (Yogyakarta: Pustaka Pelajar, 2008), 344.
} 
a. Take their own initiative freely.

b. Not influenced by outsiders, to change the system or values upheld.

\section{Creative Business Group}

Quoted by AP. Hadi, According to Devito (1997) that a group of individuals small enough to communicate easily is called a group. Wherewith each other the members relate to some of the same goals and have a structure or some kind of organization between them. then norms or rules are developed to identify what is desired for all group members. So, the group has the following characteristics: ${ }^{8}$

a. Consists of two or more people.

b. Interact with each other.

c. Have the same goal.

d. Seeing himself as part of a group.

While business is a synonym of power, effort, endeavor and so on, so that the word business group means a group of people who are organized and create a group that usually has one thing in common in its goals, so that they merge into one in the field of business interest, namely sales, trade, doing business, or entrepreneurship. Regarding the word creative, in "Creative Business Community", word is taken from the community concept of the business that the community is engaged in, namely the Creative Economy.

According to economist Paul Romer (1993) cited by Waluyo, et al, ideas are very important economic goods, more important than objects emphasized in most economic models. The creative economy is an economic concept in a new era where Human Resources (HR) is the main production factor in its economic activities. Information and creativity are carried out by relying on ideas, knowledge, skills, and talents, rather than human resources. So that knowledge is needed about self-potential and the cultural environment in each village by the people themselves. ${ }^{9}$

\section{Urban Community}

People who live in cities are referred to as urban communities, because the people in Menteng village RT 05/RW XII, are diverse from various ethnic groups. A tribe is a group of people who identify themselves with each other based on lineage. The impact of the population migration program and urban development, the majority of ethnic communities in RT 05/RW XII are Dayak, Banjar, and Javanese. Meanwhile, the languages most widely used and easy to use by the community are Indonesian and Banjarese, followed by Javanese and Dayak languages.

The ethnic groups here are divided into three more or less equal parts, such as the Dayak $40 \%$, Banjar 30\%, and Javanese 30\%. Broadly speaking, each tribe consists of sub-tribes that are diverse again if each pair of family heads is recorded regarding their hometown. The process of inter-tribal marriages, activities to try their luck in people's villages or migrate, and others make the tribes here seem to unite and tolerate each other to understand each other's languages, this is one of the characteristics that are suitable for urban society.

Recorded population data at the beginning of 2021 reached 125 families. A total of 193 people (39.95\%) of the male population and 290 people $(60.05 \%)$ of the female population, with a total population of 483 people. Overall, for both natives and immigrants, the religion of the community here is the majority of Islam as much as $75 \%$. Followed by Christianity (Catholic and Protestant) $15 \%$ and Hinduism $10 \%$.

People's livelihoods in the productive age, namely the age range of 15-64 years, are divided into 2 types of work, namely private and public. The private sector (laborers or builders,

\footnotetext{
${ }^{8}$ Agus Purbathin Hadi, Konsep Pemberdayaan, Partisipasi, 11.

${ }^{9}$ Waluyo dan Ayu Intan Sari, Penguatan Ekonomi Kreatif Masyarakat Lereng Merapi Melalui Peningkatan Keterampilan dan Produktivitas Usaha, 307. Diakses pada 23 Maret 2021, dari https://pspkumkm.lppm.uns.ac.id/
} 
rice and vegetable farmers, and traders) are around 75\% and employees (state) are around $25 \%$. Judging from their work, their average free time is in the late afternoon, and Saturdays and Sundays are said to be rest days for some people.

Communities that have been assessed as Prosperous or above the average are 3 Heads of Families or $2.4 \%$. The middle class and above are 12 families or $9.6 \%$, and the middle class is $72 \%$. Meanwhile, people with welfare below the average or underprivileged are about 20 households or $16 \%$. Of the 20 members in this creative business group, there are 2 families who are underprivileged, 4 families who are middle and upper class, and 14 families who are in middle positions.

\section{Da'wa bil Hal}

Derived from Arabic, the word Da'wah is $d a^{\prime} a-y a d ' u$ (calling and inviting). ${ }^{10}$ It can be seen that da'wah activities are not just conveying but inviting, namely amar ma'ruf and nahi munkar which means enjoining good and preventing evil.11 Imam Muslim conveyed three stages of the da'wah method, namely, bil Hal (real action), bil Lisan, and bil Qolm (heart). ${ }^{12}$

According to M. Quraish Shihab in Tafsir Al Mishbah, Qur'an Ali Imran verse 104 the word minkum has two meanings, namely part, and explanation. Meaning The explanation is related to the command to every Muslim to preach according to their respective abilities, but over time the word is very suitable to mean some groups who are specifically tasked with preaching. The command of da'wah, contained in two meanings yad'una (inviting) to goodness and ya'muruna (ordering) to carry out proselytizing da'wah, and prohibiting evil.13

The Mu'minin explained that Da'wah bil Hal means conveying Islamic teachings with real practice. The meaning is all efforts to invite people, individually or in groups, to develop themselves and society towards better social, economic, and needs according to Islamic Guidance. Emphasizing community problems with a real form of charity, ${ }^{14}$ namely helping them out of problems is worth worship and has the connotation of Da'wah.

\section{a. Group Management}

Islam is here to be a guide for all humans, as a way of life from its creator that must be followed if you want to survive in the journey of life. ${ }^{15}$ The thoyyibah life community will be created with human values through Da'wah as stated in Qur'an Ali Imran (3): 110,16 about the advantages of Muslims, compared to other people, "You are the best people who were born for humans, enjoining the right and forbidding the evil, and believing in Allah". ${ }^{17}$ Community groups are referred to as organizations, namely a group of people who have certain goals and purposes. Below is a verse that tells of a community group or ummah, must have a vision and mission in life or as ushbah.

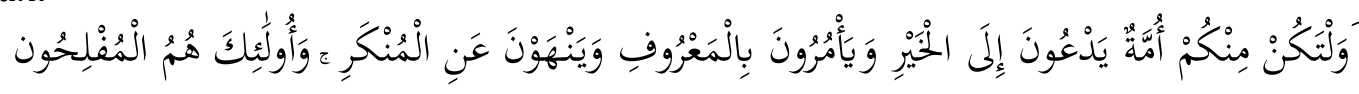

\footnotetext{
${ }^{10}$ Departemen Agama RI, Al-Qur'an dan terjemahnya, 310.

${ }^{11}$ Hamzah Tualeka ZN, Pengantar Ilmu Dakwah, (Surabaya: Alpha, 2005), 1-3.

12 A. Saiful Mu'minin, "Konstruksi Simbolik Dakwah bil

Hal dalam Film Hafalan Shalat Delisa”, Skripsi, KPI FDK UIN Syarif Hidayatullah Jakarta, 2014, 17-18.

${ }^{13}$ M. Quraish Shihab, Tafsir Al-Mishbah: Pesan,

Kesan, dan Keserasian Al-Qur'an, (Jakarta: Lentera Hati, 2002), 173-174.

${ }^{14}$ A. Saiful Mu'minin, Konstruksi Simbolik Dakwah, 19.

${ }^{15}$ Moh. Ali Aziz, Ilmu Dakwah, (Surabaya: Kencana Prenada Media Group, 2008),113.

16 Enjang AS dan Agus Ahmad Safe'i, Ilmu Dakwah: Kajian Berbagai Aspek, (Bandung: Pustaka Bani Quraisy, 2004), 10.

17 Departemen Agama RI, Al-Qur'an dan terjemahnya, 94.
} 
Translation of Qur'an Ali Imran verse 104, "And let there be among you a group of people who call to righteousness, enjoin the good and forbid the evil; they are the lucky ones.". 18 Quoted by Irfan Afandi in the Encyclopedia of Al-Qur'an, Dawam Raharjo explained that the word Ummah in the verse is not synonymous with society, but indicates a part of society that carries out a certain function. Some interpreters understand it as ushbah or League, association, organization, association. ${ }^{19}$

The organization is likened to a tool for gathering and cooperating rationally, systematically, planned, guided, and controlled to achieve organizational goals. ${ }^{20}$ Thus, the creative business group is part of the community that carries out its function as a driving force for the community in carrying out its goals related to strengthening the economy and protecting the environment.

\section{b. Economic Strengthening}

Being able to run and develop a business is the next improvement that is expected. So that people can rule over themselves, awareness of participation is needed in contributing to life.21 To strengthen their economy and maintain the sustainability of business groups, the community here tries to manage business groups well. The ultimate goal of community empowerment is found in the word independent or community independence, and this ability is built to develop themselves in a sustainable manner.

When the community feels the impact of the pandemic, the enthusiasm of the group members is able to awaken, just as adversity unconsciously brings bright ideas that are more creative to innovate. This is one form of Da'wah bil Hal, with a touch of real action, it can invite the community together not to fall and move to be empowered even during the pandemic period which is carried out by the community themselves and is still accompanied by a facilitator. Remembering Allah is the One who guarantees human life and sustenance, as stated in the Qur'an Hud (11): 6.

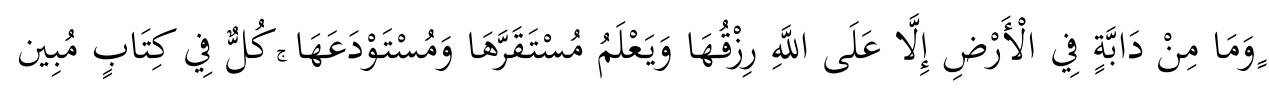

Translation of Qur'an Hud (11): 6, "And there is not a creeping animal on the earth except that it is Allah Who provides for its sustenance, and He knows its dwelling place and its place of storage. Everything is written in the real Book (Lauh mahfuzh)".22 According to Quraish Shihab in Tafsir Al-Mishbah, the guarantee of sustenance given does not mean giving it without effort, because everything has been spread out by the earth and sky and their contents. But Allah SWT. implies that the guarantee is for all dabbah, i.e. those who move. ${ }^{23}$ Not staying silent or just waiting for sustenance is the basic understanding of other meanings, namely sustenance from the smallest or hidden animals even though Allah knows and has arranged their sustenance in the book of Lauhul Mahfuz.24

\section{c. Maintain Cleanliness}

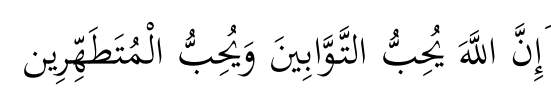

In line with the way of da'wah bil-hal, the translation of the verse that advocates environmental cleanliness in Qur'an Al-Baqarah verse 222, ".... Verily, Allah loves those who

\footnotetext{
${ }^{18}$ Departemen Agama RI, Al-Qur'an dan terjemahnya, 93.

${ }^{19}$ Irfan Afandi, “Manajemen Organisasi dalam Al-Qur'an (Kajian Qur'an. Ali Imran: 104 dalam Perspektif Manajemen Pendidikan Islam), Ar-Risalah, Vol. XVI, No. 2 Oktober 2015, 44 dan 46.

${ }^{20}$ Irfan Afandi, Manajemen Organisasi, 47.

${ }^{21}$ Hasan Bisri, Filsafat Dakwah, (Surabaya: Dakwah Digital Press, 2016), 17-18.

22 Departemen Agama RI, Al-Qur'an dan terjemahnya, 327.

${ }^{23}$ M. Quraish Shihab, Tafsir Al-Mishbah, 194-195.

${ }^{24}$ M. Quraish Shihab, Tafsir Al-Mishbah, 193.
} 
repent and loves those who purify themselves". ${ }^{25}$ Islam really teaches the issue of cleanliness, both the cleanliness of the soul, body, and environment. Cleanliness is so important that people who maintain cleanliness or clean themselves will be loved by Allah SWT.26, According to Quraish Shihab in Tafsir Al-Mishbah the verse means, "Repentance is purifying oneself from inner (spiritual) impurities while purifying oneself is from external (physical) dirt or visible and shaped by bathing or performing ablution".27

\section{Methods}

The research method in this action research uses the ABCD (Asset-Based Communitydriven Development) Approach or has a keyword by utilizing existing Community Assets. The $\mathrm{ABCD}$ approach is a continuation of CD (Community-driven Development) itself, namely community-driven development. The process by which a group of people (in a joint activity, organization, village, or urban village) are motivated by a challenge or opportunity. Then mobilize themselves to do something without being directed by outside institutions, by relying on their own resources and still having control even though there will be involvement from outside parties.

The steps or systematics taken are inculturations, applying 5-D steps, namely Discovery (Approaching and Excavation on data and assets), Dream (Finding Assets of Hope), then analyzed using Low Hanging Fruit to determine the priority of the many existing assets. Next is Design (drawing the planned program), Destiny (Definite Preparation for Action), and Define (Action), as well as the Monitoring and Evaluation Stage which is usually processed together with the Reflection stage.

\section{Results and Discussion}

The initial step taken was to ask for permission from the Head of RT 05, and continued to visit and ask for permission to the Head of RW XII. Then visit people's homes that don't look busy, either just to say hello and have a light interview. So that for 3 months running at the end of 2020 the author made observations and small research by looking at the success of one of the groups in developing community capacity in creativity skills in processing used tires into useful value, making environmental parks and Menteng urban parks. The author continues to monitor and even merge by participating in activities in the community during his spare time to better recognize and understand the community. In order to get to know each other, the author is willing to participate in activities in the community. While doing mapping, transects (area exploration), casual interviews, and others.

\section{Discovery}

Activities to identify assets with the aim of developing the environment, the community has known success stories in the past related to their potential as an independent food village and was subsequently named a clean and creative healthy village representing Menteng Village in 2020. Even in line with the planned development business, the community has established a market. night at G.Obos X parent, so it is sufficient to have experience in market operations. All of this is done, because the community has aspirations as a tourist village, both food and marine (Utilizing drainage).

\footnotetext{
25 Departemen Agama RI, Al-Qur'an dan terjemahnya, 54.

26 Faqihuddin, "membangun lingkungan bersih dan indah", Diakses pada 27 Juli 2021 dari http://kotapekalongan.kemenag.go.id/

${ }^{27}$ M. Quraish Shihab, Tafsir Al-Mishbah, 223.
} 


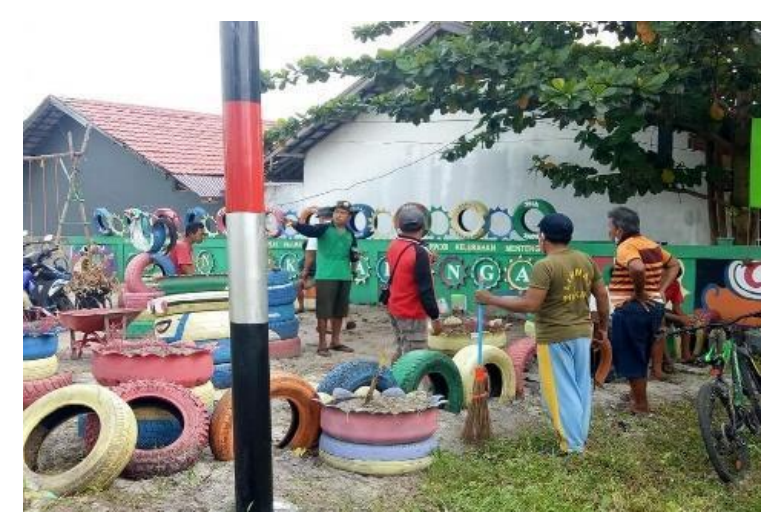

Figure 2 Community Service RT 05/RW XII

The business group cooperates with the RT apparatus, discussing directly with other communities regarding this matter, namely taking advantage of the moment to meet directly with the community during community service activities. Community service is one of the monthly work programs for RT staff. This activity can bring together many people and eventually interact with each other in the midst of their respective busy lives.

Table 1 Asset Potential

\begin{tabular}{|c|l|l|l|}
\hline Number & Type Asset & \multicolumn{1}{|c|}{ Asset Form } & \multicolumn{1}{|c|}{ Benefit } \\
\hline 1. & Human & $\begin{array}{l}\text { Community members in } \\
\text { creative business groups. }\end{array}$ & $\begin{array}{l}\text { There are permanent members who are } \\
\text { committed to the program process. }\end{array}$ \\
\hline 2. & Natural & Empty land & $\begin{array}{l}\text { For business stalls because of the } \\
\text { strategic location. }\end{array}$ \\
\hline 3. & $\begin{array}{l}\text { Social } \\
\text { Capital }\end{array}$ & Mutual Cooperation Culture & $\begin{array}{l}\text { Business development is carried out } \\
\text { independently. }\end{array}$ \\
\hline
\end{tabular}

It did not stop there, the plan was again discussed at the WA Community Group, especially in the RT 05/RW XII environment. This resulted in an agreement for the realization of holding a meeting or casual talk on February 28, 2021, by inviting all people who were not busy and interested in the discussion, especially representatives of creative business group members, which at that time only had 10 members.

This casual meeting can be called a Group Discussion with the theme of Environment and Economics, the authors together with the RT Tool have designed simple questions that are packaged lightly to explore and direct the conversation using the ORID Technique. So find assets and potential that suit the needs of the community.

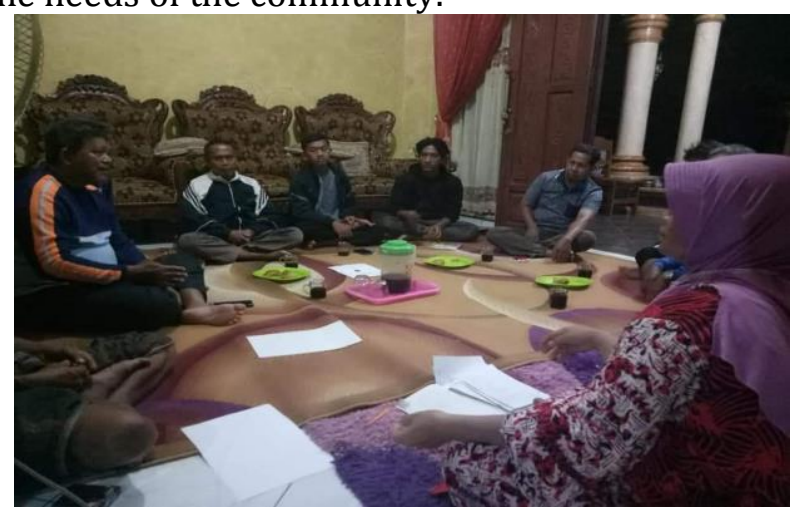

Figure 3 First Meeting on Sustainable Groups 


\section{Dream}

The priority of these assets is intervening with the aspirations or dreams of the community, especially the plan for the RT device program in 2019 and with the community. The plan is to make their environment into a Tourism Village, which is able to make their village more independent.

\section{Design}

According to Dun Steinhoff and John F. Burgess, quoted by B. Alma, entrepreneur is an actor whose job is to organize, manage, and dare (ready) to experience any loss (risk), in creating and starting a new business (business opportunity). ${ }^{28}$ Derived from the word entrepreneur (business actor), entrepreneurship is defined as a process of creation that begins with capital, then develops creative, innovative, and competitive characteristics, and develops (sustainably). So, the concept of entrepreneurship is said to be a process in improving living standards towards a real prosperous economy. ${ }^{29}$ So that a prosperous economy can be created as a result of the development of a well-managed business. The program design can be summarized as follows.

a. In the group, the members are determined to strengthen the management structure and create more complete administrative data related to creative business groups.

b. Meanwhile, in business development, they agreed to create an Angkringan Wsiata Park.

The rough design agreed by the community with the concept of the creative economy is to highlight the group's unique creations in new development businesses combined with angkringan stall rental business. The strategy to make the location crowded with visitors or have added value is to use Balanga Park which has the characteristic of processed used tires as the main icon at this time, the same concept is applied to the furniture or infrastructure used. In addition, the program is carried out independently.

\section{Define}

Together with RT 05 and RW XII apparatus along with several prospective members, they discussed the basic concept of their future business. The meeting was attended by a dozen prospective members because the group accepted new members to give the community the opportunity to join in full.

Followed by a meeting with 20 complete prospective members, they present and officially become members. The business group is under the protection of RT 05 because it is in the area. The results of the deliberation agreed to choose the core management or chairman, secretary, and treasurer. They made a news report for the formation of a Small Business-Creative Economy Group called "Hatantiring", which means inviting each other/hand in hand together to motivate each other.

Furthermore, the group agreed to make a development business by determining the steps to be taken in the future, namely designing the details of the development business and preparation for legality. The suitability of the completion target at this stage becomes the stage in determining which business activities will be realized next.

\footnotetext{
${ }_{28}$ Bukhari Alma, Kewirausahaan untuk Mahasiswa dan Umum, (Bandung: CV Alfabeta, 2013), 26.

${ }^{29}$ Ahmad Fadhil Al-Jufri, "Peningkatan Ekonomi Wirausaha Melalui Penguatan Kapabilitas Keluarga Petani Kacang Hijau di Desa Pambusuang Kecamatan Balanipa Kabupaten Polewali Mandar Provinsi Sulawesi Barat", Skripsi, PMI FDK UIN Sunan Ampel Surabaya, 2020, 38-39.
} 
Table 2 Program Summary

\begin{tabular}{|l|l|}
\hline Finish & $\begin{array}{l}\text { Creating an Independent Village, especially in the Economic, Social, and } \\
\text { Environmental Scope. }\end{array}$ \\
\hline Purpose & $\begin{array}{l}\text { Strengthening the Economy of Urban Communities in the Communal Scope } \\
\text { (Creative Business Groups), with Participatory Empowerment in the aspect } \\
\text { of Self-Mobilization by Strengthening Group Capacity. }\end{array}$ \\
\hline Result & $\begin{array}{l}\text { 1. Designing a New Development Business. } \\
\text { 2. Strengthening Group Management and Group Business. } \\
\text { 3. Realizing the development of business development. }\end{array}$ \\
\hline
\end{tabular}

\section{Destiny}

The development effort that is planned and agreed to be realized is to create an angkringan tourism park. In order to speed up development in the field, the business group continues to prepare locations in the field, which at least is carried out every afternoon from 15:00 to 17:30 WIB or every Saturday and Sunday according to the freest time. This activity was carried out according to the direction of the group leader. Every time the fees collected are used up, the business group returns to a meeting and evaluates activities in the field while discussing legalities whose management is assisted by the head of RT 05 .

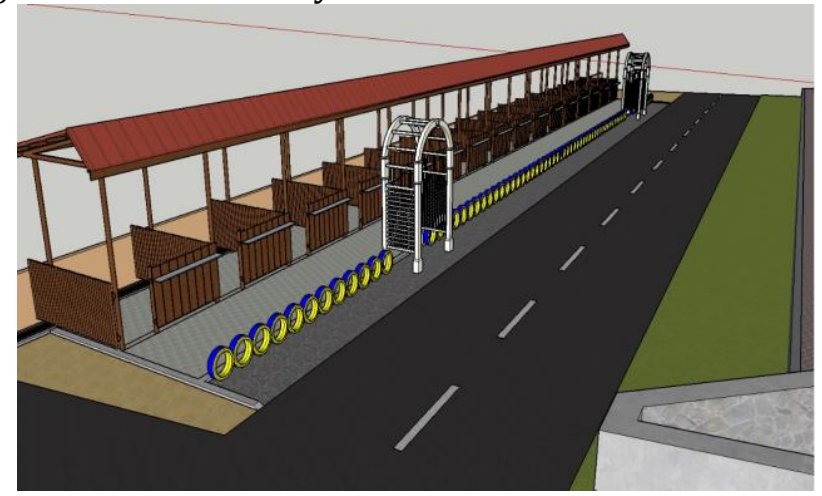

Figure 4 Visualization of Angkringan Concept

\section{a. Process in the Field:}

The location of the angkringan is on the shoulder of the G. Obos X road, so to carry out construction at this location is permitted by the Palangka Raya City government after being reviewed by the village head, PUPR service, and other related parties. Then land preparation in the field is carried out.

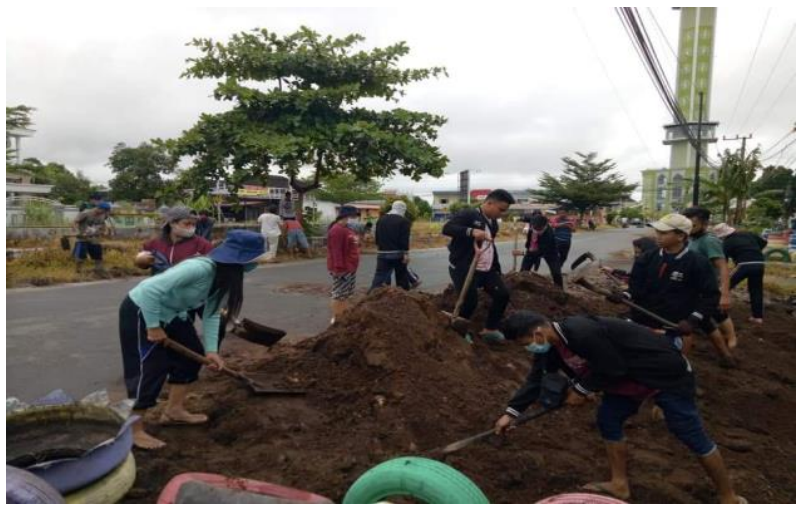

Figure 5 Soil Leveling at Angkringan Locations 
Before buying materials for the building, all members have closed the needs in the field where the calculations are handled by an experienced head craftsman, it is known that there are 3 members who have the job. After that is the process of making buildings.

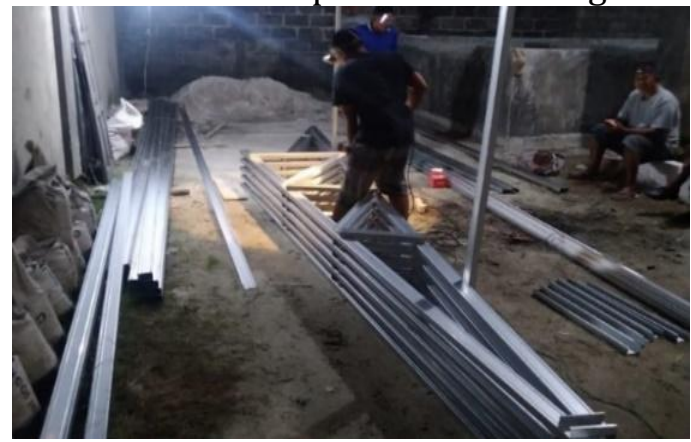

Figure 6 Assembling the Foundation and Roof of Angkringan

When assembling and installing in the field, experts are human resources that play an important role. The selection of mild steel as the material for the angkringan stalls was the result of member discussions at the fourth meeting. The considerations are price, energy, and future efficiency. If you choose wood, the consideration is that it is affordable, many people can do it, but in the future, if there is damage, the group members will spend a lot of time and energy when repairing it.

It is seen in figure 7 that the people who are members of the business group install roofs on a series of foundations made of mild steel. In terms of price, it is quite expensive, the process depends on only a few experts human resources (head craftsmen), the strength is long-lasting so it doesn't need a lot of maintenance, it saves energy and time for the future. Even if there is the demolition and at any time the land is used by the city government, materials from mild steel can still be used. All of these things were taken into account at the meeting by making the following leaky bucket analysis.

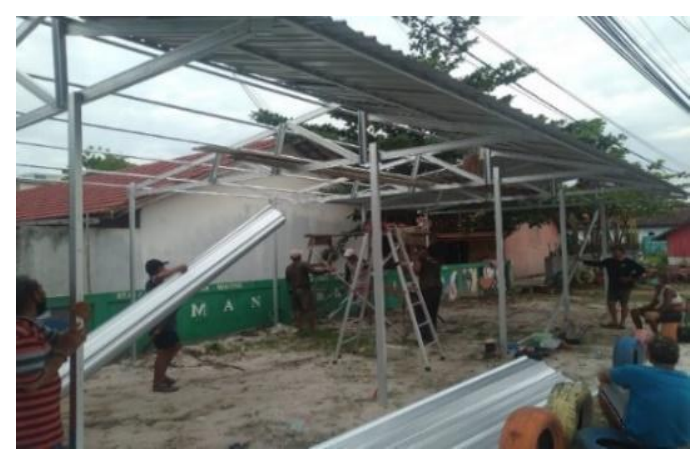

Figure 7 Making Angkringan

Table 3 Leaking Bucket Analysis Summary

\begin{tabular}{|l|l|}
\hline \multicolumn{1}{|c|}{ Aspects } & \multicolumn{1}{c|}{ Mild Steel } \\
\hline Personnel & $\begin{array}{l}\text { There are 3 experts (chief craftsman) from the members, the rest share the } \\
\text { task with the construction of other aspects. }\end{array}$ \\
\hline Initial Capital & Around 50 Million/ 20 Members \\
\hline Result & $\begin{array}{l}\text { Fixed Assets: Parks and Angkringan worth 50 million. } \\
\text { Moderate profits and low maintenance costs. }\end{array}$ \\
\hline Income & Rp. 400,000/ Month. \\
\hline Initial obstacle & The was the capital crisis so that development was carried out in stages. \\
\hline Final constraint & $\begin{array}{l}\text { Maintenance can be represented by field officers, and it saves time and } \\
\text { effort. So they can focus on the development of the next project. }\end{array}$ \\
\hline
\end{tabular}




\section{b. Group Structure Management:}

When establishing an organization, there are at least 7 stages that are passed, namely deliberation on the selection of management, then making a vision and mission, ad-art, management decrees, making organizational structures, administrative completeness, and work programs. The group worked on it in conjunction with the realization of the business stall development process. Thus, complete 7 basic stages in group management.

\section{Evaluation}

Table 4 Program Evaluation Results

\begin{tabular}{|c|c|c|}
\hline Number & Before & After \\
\hline 1. & $\begin{array}{l}\text { The group only sells } \\
\text { recycled used tires. }\end{array}$ & $\begin{array}{l}\text { Has a new business, namely Angkringan Tourism Park. } \\
\text { Combining the potential of human and environmental assets, } \\
\text { creativity (used tires) as a hallmark, and the realization of } \\
\text { village ideals. }\end{array}$ \\
\hline 2. & $\begin{array}{l}\text { Do not have the } \\
\text { capacity in good } \\
\text { group management. }\end{array}$ & $\begin{array}{l}\text { Already have the capacity and have knowledge related to good } \\
\text { management, namely there is a group structure, Vision- } \\
\text { Mission, Group Work Program, Articles of Association-Budgets, } \\
\text { and Group Decision Letters. }\end{array}$ \\
\hline \multicolumn{3}{|c|}{ History Flow } \\
\hline 1. & $\begin{array}{l}\text { The community } \\
\text { managed to build a } \\
\text { night market every } \\
\text { night of the week. }\end{array}$ & $\begin{array}{l}\text { Now the community is able to make economic activities at the } \\
\text { angkringan market, by attracting a tourist attraction, namely } \\
\text { Balanga Park. }\end{array}$ \\
\hline 2. & $\begin{array}{l}\text { Previously it was an } \\
\text { Ex-Waste } \\
\text { area. }\end{array}$ & Now as a container angkringan tourism park. \\
\hline
\end{tabular}

Evaluation can be seen by looking at the new assets that are added and by comparing past and present success stories after the program is completed or can be seen in the photographic evidence below.

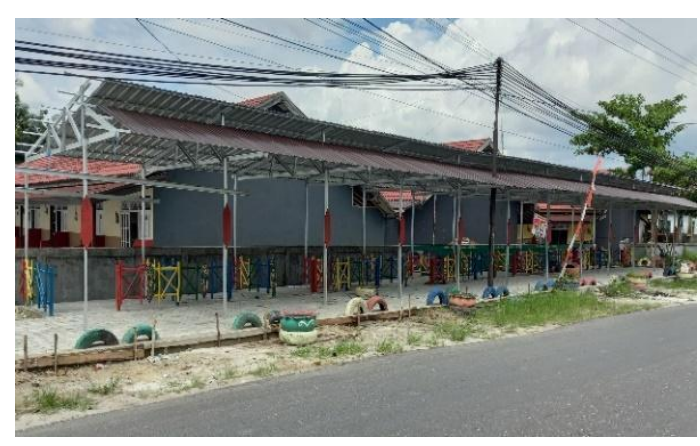

Figure 8 Angkringan Realization Results

\section{E. Conclusion}

From the explanation in the previous chapters, it can be concluded as follows.

First, strategy to develop groups with natural and human assets, mobilize people to join creative business groups, so that from 10 members to 20 members, then strengthen group management. At first there was only 1 coordinator, then there was a change, namely there was a 
core management of the chairman, secretary, treasurer, and members. Furthermore, planning and building new business developments with a leaky bucket analysis in "Angkringan Tourism Park", there are areas of responsibility. Such as finance, public relations, asset management, and the environment. Apart from that, basic management equipment is already available, such as management structure, vision-mission, ad-art, work programs, and administrative files. The realization of the construction of 12 stalls was opened and an evaluation was carried out.

Second, the creative business group "Hatantiring" includes already doing da'wah bil hal, the reason is that group members not only make a discourse but take action in the field on the designs they have designed. In Qur'an Ali Imran verse 104 states that community groups must have a clear vision and mission in order to achieve their goals. The relevance of changing people's behavior is reflected in the success of strengthening group management, where each member who is a member has their own responsibilities so that the program plan is realized. In addition, members carry out God's orders to move or be innovative in seeking sustenance (Qur'an Hud verse 6), even implementing a culture of maintaining cleanliness according to Qur'an Al-Baqarah verse 222.

\section{References}

Afandi, I., Manajemen Organisasi dalam Al-Qur'an (Kajian Qur'an. Ali Imran: 104 dalam Perspektif Manajemen Pendidikan Islam), Ar-Risalah, Vol. XVI, No. 2 Oktober (2015):

Alma, B. Kewirausahaan untuk Mahasiswa dan Umum, Bandung: CV Alfabeta, 2013.

Al-Jufri, AF. 2020. "Peningkatan Ekonomi Wirausaha Melalui Penguatan Kapabilitas Keluarga Petani Kacang Hijau di Desa Pambusuang Kecamatan Balanipa Kabupaten Polewali Mandar Provinsi Sulawesi Barat". Skripsi, PMI FDK UIN Sunan Ampel Surabaya.

AS, Enjang dan Safe'i, AA.. Ilmu Dakwah: Kajian Berbagai Aspek. Bandung: Pustaka Bani Quraisy, 2004.

Aziz, MA. Ilmu Dakwah. Surabaya: Kencana Prenada Media Group, 2008.

Bisri, H. Filsafat Dakwah. Surabaya: Dakwah Digital Press, 2016.

Departemen Agama RI. 2000. Al-Qur'an dan terjemahnya Juz 1-30, Surabaya: UD Mekar.

Faqihuddin, Membangun Lingkungan Bersih dan Indah, diakses pada 27 Juli 2021 dari http://kotapekalongan.kemenag.go.id/

Hadi, AP. Konsep Pemberdayaan, Partisipasi dan Kelembagaan dalam Pembangunan. Mataram: Yayasan Agribisnis/Pusat Pengembangan Masyarakat Agrikarya (PPMA), 2010.

Ife, J. dan Tesoriero, F. Community Development: Alternatif Pengembangan Masyarakat di Era Globalisasi. Penj. Sastrawan Manulang, dkk., Yogyakarta: Pustaka Pelajar, 2008.

Mu'minin, AS. 2014. Konstruksi Simbolik Dakwah bil Hal dalam Film Hafalan Shalat Delisa. Skripsi, KPI FDK UIN Syarif Hidayatullah Jakarta.

Shihab, MQ. Tafsir Al-Mishbah: Pesan, Kesan, dan Keserasian Al-Qur'an. Jakarta: Lentera Hati, 2002.

Shomedran, "Pemberdayaan Partisipastif dalam Membangun Kemandirian Ekonomi dan Perilaku Warga Masyarakat (Studi Pada Bank Sampah Wargi Manglayang RT 01 RW 06 Kelurahan Palasari Kecamatan Cibiru Bandung)", Jurnal Pendidikan Luar Sekolah, (online), Vol. 12, No. 2 (2016): 
Waluyo dan Sari, AI., Penguatan Ekonomi Kreatif Masyarakat Lereng Merapi Melalui Peningkatan Keterampilan dan Produktivitas Usaha, diakses pada 23 Maret 2021, dari https://pspkumkm.lppm.uns.ac.id/

ZN, Hamzah Tualeka. Pengantar Ilmu Dakwah. Surabaya: Alpha., 2005.

Zubaedi. Pengembangan Masyarakat: Waacana dan Praktek. Jakarta: Kencana, 2013. 